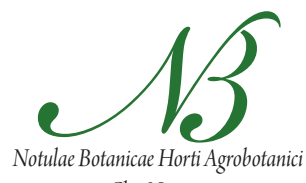

Cluj-Napoca

\title{
Seed Priming and Field Performance of Soybean (Glycine max L.) in Response to Water Limitation
}

\author{
Kazem GHASSEMI-GOLEZANI*, Somayeh FARSHBAF- \\ JAFARI, Jalil SHAFAGH-KOLVANAGH \\ University of Tabriz, Faculty of Agriculture, Department of Agronomy and Plant Breeding, \\ Tabriz,Iran; golezani@gmail.com (*correspondingauthor)
}

\begin{abstract}
Laboratory tests and a field experiment were carried out to evaluate the effects of priming methods on seed invigoration and field performance of soybean (cv. 'Zan'). The field experiment was arranged as split plot based on RCB design with three replications. Irrigation treatments $\left(\mathrm{I}_{1}, \mathrm{I}_{2}\right.$ and $\mathrm{I}_{3}$ : irrigation after 70,110 and $150 \mathrm{~mm}$ evaporation from class A pan) and priming methods (water, $3 \% \mathrm{KH} \mathrm{H}_{2} \mathrm{PO}$ and $3 \% \mathrm{KNO}_{3}$ for $8 \mathrm{~h}$ at $15 \pm 1^{\circ} \mathrm{C}$ ) were allocated to main and sub-plots, respectively. Germination percentage, seedling dry weight and field emergence percentage decreased, but mean emergence time increased, due to seed priming. Grain yield under severe water deficit was $29.32 \%$ less than that under normal irrigation. Pods per plant, grains per plant and grain yield per plant were significantly enhanced as a result of low stand establishment caused by seed priming. Consequently, biological and grain yields per unit area and also harvest index were statistically similar for plants from primed and unprimed seeds. In general, priming methods had no any beneficial effect on laboratory and field performance of soybean seeds.
\end{abstract}

Keywords: grain yield, seed priming, seedling emergence, soybean

\section{Introduction}

Soybean (Glycine max L.) is one of the most important contributors to protein and worlds edible vegetable oils. Water deficit during vegetative and reproductive stages can limit soybean growth and yield (Brown et al., 1985; Daneshian and Jonobi, 2001; Daneshian and Zare, 2005). However, it is not clear whether cultivation of high quality seeds or seed priming can reduce the deleterious effects of water limitation on soybean performance.

The use of high quality seeds with appropriate seed rate are essential to establish a suitable plant population in a soybean field for better returns (Ajouri et al., 2004; Marwat and Nafziger, 1990). Seed quality may be improved by production techniques or by seed pretreatments with water (hydro-priming), osmotic solutions (osmo-priming) and matric materials (matri-priming) (Hur, 1991; Harris et al., 1999; Kaya et al., 2008; Pill et al., 1991). Seed priming is a pre-germination treatment in which seeds are held at a water potential that allows imbibition, but prevents radicle extension (Bradford, 1986). Seed priming is a suitable method to enhance seed and seedling vigor, leading to better stand establishment and yield (Bruggink et al., 1999; Khalil et al., 2010).

The beneficial effects of seed priming have been demonstrated for many field crops such as wheat (Parera and Cantliffe, 1994), sweet corn (Chiu et al., 2002), mungbean (Khan et al., 2005), barley (Abdulrahmani et al., 2007), lentil (Ghassemi-Golezani et al., 2008), cucumber
(Ghassemi-Golezani and Esmaeilpour, 2008) and winter rapeseed (Ghassemi-Golezani et al., 2010). However, seed priming decreased germination percentage in barley and corn (Sharif et al., 2006) and reduced rate of seedling emergence and plants per unit area in sunflower (Hussain et al., 2006). This research was carried out to investigate the effects of hydro and osmotic priming on seed invigoration in the laboratory and seedling emergence and grain yield of soybean under different irrigation treatments in the field.

\section{Materials and methods}

Seeds of soybean (cv. 'Zan') were obtained from Agricultural Research Institute, Khoy, Iran. These seeds were divided into four sub-samples. A sub-sample was kept as control (unprimed) and the three other sub-samples were prepared for priming treatments. Water and $3 \% \mathrm{KH}_{2} \mathrm{PO}_{4}$ and $3 \% \mathrm{KNO}_{3}$ solutions were used to pre treat each of the sub-samples with each of these solutions for $8 \mathrm{~h}$. Priming treatments were performed in an incubator adjusted on $15 \pm 1^{\circ} \mathrm{C}$ under dark conditions. After priming, seeds were washed with tap water and then dried back to $30-40 \%$ moisture content at room temperature of $20-25^{\circ} \mathrm{C}$.

Laboratory tests were carried out as RCB design at Seed Technology Laboratory of the University of Tabriz, Iran. Four replicates of 25 seeds were placed between moist filter papers and germinated in an incubator at $15^{\circ} \mathrm{C}$ for 14 days. Germination (protrusion of radicle by $2 \mathrm{~mm}$ ) was re- 
corded in daily intervals. Mean germination time for each treatment was calculated according to Ellis and Roberts (1981). At the end of germination test (14 days), radicles and shoots were cut from the cotyledons and then dried in an oven at $75 \pm 2^{\circ} \mathrm{C}$ for 48 hours. The dried radicles and shoots were weighed and the mean seedling dry weight for each treatment at each replicate was determined.

The field experiment was conducted at the Research Farm of Tabriz university (Latitude $38^{\circ} 5^{\prime} \mathrm{N}$, Longitude $46^{\circ} 17^{\prime} \mathrm{E}$, Altitude $1360 \mathrm{~m}$ above sea level) in 2009 . The experiment was arranged as split plot using RCB design with three replications. Irrigation treatments $\left(\mathrm{I}_{1}, \mathrm{I}_{2}\right.$ and $\mathrm{I}_{3}$ : irrigation after 70,110 and $150 \mathrm{~mm}$ evaporation from class A pan) and priming methods were assigned to main and sub-plots, respectively. All plots were irrigated immediately after sowing. Irrigation treatments were applied after seedling establishment. Weeds were controlled by hand weeding during crop growth and development. The number of emerged seedlings in an area of $1 \mathrm{~m}^{2}$ within each plot was counted in daily intervals until seedling establishment stabilized. Mean emergence time was calculated similar to mean germination time.

At maturity, plants of $1 \mathrm{~m}^{2}$ in the middle part of each plot were harvested and the number of pods per plant, grains per plant, 1000 grain weight and grain yield per unit area were recorded. The data were analyzed by MSTATC software and the means were compared using Duncan multiple range test at $\mathrm{P} \leq 0.05$.

\section{Results and discussions}

Effects of seed priming on germination percentage and seedling dry weight were significant $(\mathrm{P} \leq 0.01)$, but on mean germination time was insignificant. The results indicated that germination percentage and seedling dry weight of unprimed seeds were higher than those of primed seeds (Tab. 1). Seedling emergence percentage and time were also significantly $(\mathrm{P} \leq 0.01)$ affected by seed priming. Seedlings from unprimed seeds emerged earlier than those from primed seeds (Tab. 1).

Reduction in germination percentage and seedling dry weight in the laboratory and seedling emergence percentage and rate in the field (Tab. 1) due to seed priming clearly indicate that all priming treatments have deleterious effects on soybean seed germination and seedling growth. Similar results were reported for barley, maize and oat (Sharif et al., 2006) and sunflower (Hussain et al., 2006). Pill and Kilian (2000) found that soaking parsley seeds in water or GA, decreased the germination percentage. Pill and Necker (2001) found that hydro-priming failed to improve emergence in common Kentucky bluegrass seeds. Also, soaking wheat seeds in $5 \% \mathrm{NaHCO}_{3}$ or $\mathrm{NaCl}$ for 30 min or $24 \mathrm{~h}$ decreased emergence percentage, tillers and yield (Singh and Gill, 1988).

Irrigation treatments had no significant effect on pods per plant, grains per plant, 1000 grain weight, grain yield per plant, biological yield, grain yield per unit area and harvest index of soybean in the field (Tab. 2). Although the effect of irrigation on grain yield was insignificant, but mean yield under severe water stress was $29.32 \%$ less than that under well watering. Water deficit through the reduction in the leaf area index and photosynthetic capacity reduces grain yield, because the earliest response to the leaf water deficit is stomata closure, which limits $\mathrm{CO}_{2}$ diffusion to chloroplasts (Berkowitz et al., 1983; Cornic and Masacci, 1996; Muller and Whitsitt, 1996). Reduction of

Tab. 1. Effects of priming on mean germination percentage, germination time and seedling dry weight of soybean in the laboratory

\begin{tabular}{cccccc}
\hline Pre-treatments & $\begin{array}{c}\text { Germination } \\
(\%)\end{array}$ & $\begin{array}{c}\text { Germination time } \\
(\text { day })\end{array}$ & $\begin{array}{c}\text { Seedling dry weight } \\
(\mathrm{mg})\end{array}$ & $\begin{array}{c}\text { Seedling emergence } \\
(\%)\end{array}$ & $\begin{array}{c}\text { Emergence time } \\
(\text { days })\end{array}$ \\
\hline Non-primed & $97^{\mathrm{a}}$ & $3.75^{\mathrm{a}}$ & $687.5^{\mathrm{a}}$ & $84.7^{\mathrm{a}}$ & $16^{\mathrm{c}}$ \\
Water & $77^{\mathrm{b}}$ & $3.75^{\mathrm{a}}$ & $457.5^{\mathrm{b}}$ & $41.4^{\mathrm{b}}$ & $17^{\mathrm{b}}$ \\
$\mathrm{KH}_{2} \mathrm{PO}_{4}$ & $67^{\mathrm{c}}$ & $3.25^{\mathrm{a}}$ & $337.5^{\mathrm{c}}$ & $24.6^{\mathrm{c}}$ & $18^{\mathrm{a}}$ \\
$\mathrm{KNO}_{3}$ & $31^{\mathrm{d}}$ & $3^{\mathrm{a}}$ & $142.5^{\mathrm{d}}$ & $23.2^{\mathrm{c}}$ & $18^{\mathrm{a}}$ \\
\hline
\end{tabular}

Different letters in each column indicate significant difference at $\mathrm{p} \leq 0.05$

Tab. 2. Analysis of variance of the effects of irrigation and seed priming on field performance of soybean

\begin{tabular}{|c|c|c|c|c|c|c|c|c|}
\hline \multirow[b]{2}{*}{$\begin{array}{l}\text { Source of } \\
\text { variation }\end{array}$} & \multicolumn{8}{|c|}{ MS } \\
\hline & $\mathrm{df}$ & $\begin{array}{c}\text { Pods per } \\
\text { plant }\end{array}$ & $\begin{array}{c}\text { Grains per } \\
\text { plant }\end{array}$ & $\begin{array}{c}1000 \text { grain } \\
\text { weight }\end{array}$ & $\begin{array}{c}\text { Grain yield } \\
\text { per plant }\end{array}$ & $\begin{array}{c}\text { Biological } \\
\text { yield }\end{array}$ & $\begin{array}{c}\text { Grain yield } \\
\text { per unit }\end{array}$ & $\begin{array}{c}\text { Harvest } \\
\text { index }\end{array}$ \\
\hline Replication & 2 & $188.1^{\mathrm{ns}}$ & $620.4^{\mathrm{ns}}$ & $1450.8^{\mathrm{ns}}$ & $52.6^{\mathrm{ns}}$ & $1936.5^{\text {ns }}$ & $1694.9^{\text {ns }}$ & $78.3^{\text {ns }}$ \\
\hline Irrigation(I) & 2 & $1445.7^{\mathrm{ns}}$ & $7424.1^{\mathrm{ns}}$ & $583.1^{\mathrm{ns}}$ & $77.2^{\mathrm{ns}}$ & $66473.3^{\text {ns }}$ & $9075^{\mathrm{ns}}$ & $53.8^{\mathrm{ns}}$ \\
\hline Error & 4 & 1015.7 & 6449.2 & 426.8 & 119.3 & 12386.1 & 5103.4 & 31.2 \\
\hline Priming $(\mathrm{p})$ & 3 & $4516.8^{\prime \prime}$ & $28812^{\prime \prime}$ & $59.9^{\mathrm{ns}}$ & $625.8^{*}$ & $1541^{\text {ns }}$ & $171^{\text {ns }}$ & $13.2^{\mathrm{ns}}$ \\
\hline $\mathrm{I} \times \mathrm{P}$ & 6 & $313.3^{\text {ns }}$ & $1674.7^{\mathrm{ns}}$ & $58.1^{\mathrm{ns}}$ & $35.1^{\mathrm{ns}}$ & $11570.6^{\text {ns }}$ & $3529.4^{\mathrm{ns}}$ & $13.6^{\mathrm{ns}}$ \\
\hline Error & 18 & 297.9 & 1662.1 & 137.3 & 47.5 & 10142.8 & 2638.9 & 19.7 \\
\hline C.V (\%) & & 36.38 & 36.80 & 8.38 & 44.17 & 33.55 & 34.61 & 8.83 \\
\hline
\end{tabular}

$\mathrm{ns},{ }^{*}$ and ${ }^{* *}$ : No significant and significant at $\mathrm{p} \leq 0.05$ and $\mathrm{p} \leq 0.01$, respectively 
Tab. 3. Means of field traits for soybean affected by seed priming

\begin{tabular}{cccccccc}
\hline Pre-treatment & $\begin{array}{c}\text { Pods per } \\
\text { plant }\end{array}$ & $\begin{array}{c}\text { Grains per } \\
\text { plant }\end{array}$ & $\begin{array}{c}1000 \text { grain weight } \\
(\mathrm{g})\end{array}$ & $\begin{array}{c}\text { Grain yield } \\
(\mathrm{g} / \text { plant })\end{array}$ & $\begin{array}{c}\text { Biological yield } \\
\left(\mathrm{gm}^{-2}\right)\end{array}$ & $\begin{array}{c}\text { Grain yield } \\
\left(\mathrm{gm}^{-2}\right)\end{array}$ & $\begin{array}{c}\text { Harvest index } \\
(\%)\end{array}$ \\
\hline Non-primed & $10^{\mathrm{b}}$ & $21.2^{\mathrm{b}}$ & $138.6^{\mathrm{a}}$ & $5.8^{\mathrm{b}}$ & $315.6^{\mathrm{a}}$ & $154^{\mathrm{a}}$ & $48.6^{\mathrm{a}}$ \\
Water & $19.6^{\mathrm{ab}}$ & $44.3^{\mathrm{ab}}$ & $136.7^{\mathrm{a}}$ & $11.9^{\mathrm{b}}$ & $290.9^{\mathrm{a}}$ & $149.1^{\mathrm{a}}$ & $51^{\mathrm{a}}$ \\
$\mathrm{KH}_{2} \mathrm{PO}_{4}$ & $30^{\mathrm{a}}$ & $71.3^{\mathrm{a}}$ & $141.4^{\mathrm{a}}$ & $20.1^{\mathrm{a}}$ & $288^{\mathrm{a}}$ & $143.5^{\mathrm{a}}$ & $51.4^{\mathrm{a}}$ \\
$\mathrm{KNO}_{3}$ & $35.2^{\mathrm{a}}$ & $84.6^{\mathrm{a}}$ & $142.4^{\mathrm{a}}$ & $24.5^{\mathrm{a}}$ & $303.6^{\mathrm{a}}$ & $147.1^{\mathrm{a}}$ & $50.2^{\mathrm{a}}$ \\
\hline
\end{tabular}

Different letters in each column indicate significant difference at $\mathrm{p} \leq 0.05$

the plant growth and grain yield due to water deficit has also been reported for millet (Kumari, 1988; Mahalakshmi and Bidinger, 1985), rice (Yao et al., 1990), chickpea (Probhakar and Safar, 1990; Singh, 1991), sorghum (Berenguuer and Faci, 2001), common bean (Adiku et al., 2001; Ghassemi-Golezani and Mardfar, 2008), soybean (Mirakhori et al., 2009; Paknejad et al., 2009) and faba bean (Ghassemi-Golezani et al., 2009).

Pods per plant, grains per plant and grain yield per plant of soybean were significantly affected by priming $(\mathrm{P} \leq 0.01)$, but it had no significant effect on 1000 grain weight, biological yield, grain yield and harvest index (Tab. 2). Pods per plant, grains per plant and grain yield per plant were significantly enhanced by seed priming, particularly by priming with $\mathrm{KNO}_{3}$ (Tab. 3). However, the interaction of irrigation $\times$ priming was insignificant for yield and yield components of soybean (Tab. 2).

Seed priming resulted in lower plant population density, compared with that of control (Tab. 1). These plants were able to use available resources more efficiently, because of low rivalry among plants (Dahmardeh et al., 2010; Taheri-Asghari et al., 2009). This was resulted in production of more pods per plant, grains per plant and grain yield per plant, compared with those from unprimed seeds (Tab. 3). In other words, reduction in plant density due to seed priming was largely compensated by improvements in individual plant performance. Consequently, biological and grain yields per unit area and also harvest index did not differ significantly between plants from primed and unprimed seeds (Tabs. 2 and 3).

\section{Conclusions}

Germination percentage, seedling dry weight and field emergence percentage and rate of soybean decreased as a result of seed priming. Pods per plant, grains per plant and grain yield per plant were significantly improved due to low stand establishment caused by seed priming. This was resulted in statistically similar biological and grain yields per unit area and also harvest index for plants from primed and unprimed seeds. Therefore, priming treatments has no any beneficial effect on laboratory and field performance of soybean seeds.

\section{References}

Abdulrahmani B, Ghassemi-Golezani K, Valizadeh M, Feizi-Asl $\mathrm{V}$ (2007). Seed priming and seedling establishment of barley (Hordeum voulgare L.). J Food Agric Environ 5:179-184.
Adiku SGK, Renger M, Wessolek G, Facklan M, Hecht-Bucholtz C (2001). Simulation of the dry matter production and seed yield of common beans under varying soil water and salinity conditions. Agric Water Management 47:55-68.

Ajouri A, Haben A, Becker M (2004). Seed priming enhances germination and seedling growth of barley under conditions of $\mathrm{P}$ and Zn deficiency. J Plant Nutrition Soil Sci 167:630636.

Berkowitz GA, Chen C, Gibbs M (1983). Stomatal acidification mediates in vivo water stress inhibition of onstomatalcontrolled photosynthesis. Plant Physiol 72:1123-1126.

Berenguuer MJ, Faci JM (2001). Sorghum (Sorghum bicolor) yield compensation processes under different plant ensities and variable water supply. Eur J Agron 15:43-55.

Bradford KJ (1986). Manipulation of seed water relations via osmotic priming to improve germination under stress conditions. Hort Sci 21:1105-1112.

Brown EA, Canviness CE, Brown DA (1985). Response of selected soybean cultivars to soil moisture deficit. Agron J 77:274-278.

Bruggink GT, Ooms JJJ, Van der Toorn P (1999). Induction of longevity in primed seeds. Seed Sci Res 9:49-53.

Chiu KY, Chen CL, Sung JM (2002). Effect of priming temperature on storability of primed Sh-Z sweet corn seed. Crop Sci 42:1996-2003.

Cornic G, Masacci A (1996). Leaf photosynthesis under drought stress, 347-366 p. In: Baker NR (Ed.). Photosynthesis and The Environment. Kluwer Academic Publishers.

Dahmardeh M, Ramroodi M, Valizadeh J (2010). Effect of plant density and cultivars on growth, yield and yield components of faba bean (Vicia faba L.). Afr J Biotechnol 9:8643-8647.

Daneshian J, Zare D (2005). Diversity for resistance drought on soybean. J Agric Sci 1:23-50.

Daneshian J, Jonobi P (2001). Effect of drought stress and different calcium on characters soybean. Agric Sci 1:95108.

Ellis RA, Roberts EH (1981). The quantification of ageing and survival in orthodox seeds. Seed Sci Technol 9:373-409.

Ghassemi-Golezani K, Aliloo AA, Valizadeh M, Moghaddam M (2008). Effects of different priming techniques on seed invigoration and seedling establishment of lentil (Lens Culinaris Medik.). J Food Agric Environ 6:222-226.

Ghassemi-Golezani K, Esmaeilpour B (2008). The effect of salt priming on the performance of differentially matured cucumber (Cucumis sativus) seeds. Not Bot Horti Agrobo 36:67-70. 
Ghassemi-Golezani K, Ghanehpoor S, Dabbagh Mohammadi Nasab A (2009). Effects of water limitation on growth and grain filling of faba bean cultivars. J Food Agric Environ $7: 442-447$.

Ghassemi-Golezani K, Jabbarpour S, Zehtab-Salmasi S, Mohammadi A (2010). Response of winter rapeseed (Brassica napus L.) cultivars to salt priming of seeds. Afr J Agric 5:1089-1094.

Ghassemi-Golezani K, Mardfar RA (2008). Effects of limited irrigation on growth and grain yield of common bean. J Plant Sci 3:230-235.

Harris D, Joshi A, Khan PA, Gothkar P, Sodhi PS (1999). Onfarm seed priming in semi-arid agriculture development and evaluation in maize, rice and chickpea in India using participatory methods. Exper Agric 35:15-29.

Hur SN (1991). Effect of osmo conditioning on the productivity of Italian ryegrass and sorghum under suboptimal conditions. Korean J Animal Sci 33:101-105.

Hussain M, Farooq M, Basra SMA, Ahmad N (2006). Influence of seed priming techniques on the seedling establishment, yield and quality of hybrid sunflower. Int Agric Biol 8:1418.

Kaya M, Kaya G, Kaya MD, Atak M, Saglam S, Khawar KM, Ciftci CY (2008) Interactions between seed size and $\mathrm{NaCl}$ on germination and early seedling growth of some Turkish cultivars of chickpea (Cicer arietinum L.). J Zhejiang Univ Sci B (JZUS-B) 9:371-377.

Khalil SK, Mexal JG, Rehman A, Khan AZ, Wahab S, Zubair M, Khalil IH, Mohammad F (2010). Soybean mother plant exposure to temperature stress and its effect on germination under osmotic stress. Pak J Bot 42:213-225.

Khan A, Khalil SK, Khan S, Afzal A (2005). Priming affects crop stand of mungbean. Sarhad J Agric 21:535-538.

Kumari S (1988). The effects of soil moisture stress on the development and yield of millet. Agron J 57:480-487.

Marwat KB, Nafziger ED (1990). Cocklebur and Velvet leaf interference with soybean grown at different densities and planting patterns. Agron J 82(3):531-534.

Mahalakshmi V, Bidinger FR (1985). Flowering response of pearl millet to water stress during panicle development. Ann Appl Biol 106:571-578.

Mirakhori M, Paknejad F ,Moradi F, Ardakani M, Zahedi H, Nazeri P (2009). Effect of drought stress and methanol on yield and yield components of soybean max (L 17). Am J Biochem Biotechnol 5 (4):162-169.
Muller JE, Whitsitt MS (1996). Plant cellular response to water deficit. Plant Growth Regul 20:41-46.

Parera CA, Cantliffe DJ (1994). Pre-sowing seed priming. Hort Rev 16:109-139.

Paknejad F, Mirakhori M, Jami Al-Ahmadi M, Tookalo R, Pazoki AR, Nazari P (2009). Physiological response of soybean (Glycine max) to foliar application of methanol under different soil moistures. American J Agric Biol Sci 4:311-318.

Pill WG, Kilian EA (2000). Germination and emergence of parsley in response to osmotic or matric seed priming and treatment with gibberllin. Hort Sci 35:907-909.

Pill WG, Necker AD (2001). The effects of seed treatments on germination and establishment of Kentucky bluegrass (Poapratense L.). Seed Sci Technol 29:65-72.

Pill WG, Frett JJ, Morneau DC (1991). Germination and seedling emergence of primed tomato and asparagus seeds under adverse conditions. Hort Sci 26:1160-1162.

Probhakar M, Safar CS (1990). Dry-matter accumulation and distribution in chickpea (Cicer arietinum) genotype, phosphorus source and irrigation level. Indian J Agric Sci 60:204-206.

Sharif A, Anwar F, Bakht J, Anwar S, Akhter S (2006). Effect of different seed priming methods on the germination of various cereals. Sarhad J Agric 22:2-5.

Singh P (1991). Influence of water deficits on phenology, growth and dry-matter allocation in chickpea (Cicer arietinum L.). Field Crops Res 28:1-15.

Singh H, Gill HS (1988). Effect seed treatment with salts on germination and yield of wheat. Agric Sci Digest 8:173175.

Taheri-Asghari M, Daneshian J, Aliabadi Farahani H (2009). Effects of drought stress and planting density on quantity and morphological characteristics of chicory (Cichorium intybus L.). Asian J Agric Sci 1:12-14.

Yao NR, Goue B, Kouadio K, Hainnaux G (1990). Effects of plant density and soil moisture on growth indices of two upland rice varieties. Agron Afr 2:7-14. 